\title{
Measurement of Scale Efficiency in Dairy Farms: Data Envelopment Analysis (DEA) Approach
}

\author{
Bassam Aldeseit ${ }^{1}$ \\ ${ }^{1}$ Department of Agricultural Economics and Extension, Faculty of Agriculture, Jerash University, P.O. Box 311, \\ Jerash 26150, Jordan \\ Correspondence: Bassam Aldeseit, Department of Agricultural Economics and Extension, Faculty of Agriculture, \\ Jerash University, P.O. Box 311, Jerash 26150, Jordan. E-mail: Bkhitan2@yahoo.com
}

Received: June 5, 2013 Accepted: July 10, 2013 Online Published: August 15, 2013

doi:10.5539/jas.v5n9p37 URL: http://dx.doi.org/10.5539/jas.v5n9p37

\begin{abstract}
This study aimed at evaluating the performance of sampled dairy farms using farm level technical and scale input oriented efficiencies. To achieve the objective of the study Data Envelopment Analysis (DEA) was used to analyze data collected from 120 dairy farms in Jordan. Scale efficiency scores were estimated using constant return to scale and variable return to scale DEA models. The results revealed that the sampled farms were not operating at an optimal size. On average, the scale efficiency estimated at approximately 0.66 , indicating scale-inefficiency under both constant returns to scale and variable returns to scale. This inefficiency indicates that the sampled dairy producers were overusing inputs to produce their level of output. To increase scale of operation dairy farmers in Jordan should increase the overall degree of technical efficiency. Extension services can assist in identifying the best management practices on how to improve farms technical efficiency.
\end{abstract}

Keywords: scale efficiency, optimal scale, dairy farms, frontier production functions, data envelopment analysis

\section{Introduction}

Jordan is a developing country in which dairy farming considered very important among other livestock production sectors. In Jordan, the number of dairy farms is 628 with a capacity of 67590 heads; family operates most of these farms. They are with a small scale (Alsharafat, 2013). The average number of heads per farm is 108 . The dairy sector contributes more than $50 \%$ of total livestock production in the country. According to the records of the Ministry of Agriculture in 2011, dairy farms provide nearly $77 \%$ of the total quantity of fresh milk in the country. Dairy farms in Jordan produced a quantity of 238569 Metric Tons (MT) of fresh milk with a value of $132,307,431$ USD out of 306936 MT produced in that year (Ministry of Agriculture or MoA, 2011). These farms also produced another important product, which is organic fertilizer. The quantity of organic fertilizer produced by dairy farms in the country in the year 2011 was nearly 36500 MT with a value of 501,347 USD (MoA, 2011).

In developing countries, it is very important to measure the efficiency of agricultural production. This measurement is useful for agricultural production policies (Russell \& Young, 1983). Many studies investigated the efficiency of dairy farms; these include Fraser and Coridna (1999), Mbaga et al. (2002), and Dalton (2004).

Based on Farrell (1957) analysis, methodologies of efficiency measurement such as the parametric Stochastic Frontier Analysis (SFA) and the non-parametric Data Envelopment Analysis (DEA) were developed (Aigner et al., 1977; Charnes et al., 1978). To compare these two methodologies of efficiency measurement, DEA methodology, which was adopted in this study, does not need a functional form of the production frontier that its specification may lead to biased results as Brnes (2006) noted. DEA has been widely used in dairy farms efficiency studies (Jaforullah \& Whiteman, 1999; Latruffe et al., 2005; Barnes, 2006; Minh \& Long, 2009; D’Haese et al., 2009). DEA method originally proposed by Charnes et al. (1978). It employs linear programming to estimate the most efficient production frontier. The present study makes use of this non-parametric DEA to estimate the efficient frontier because any priori specification of the functional form of the production function is not required (Seiford \& Thrall, 1990; Kalaitzandonakes et al., 1992). Another important reason is that the knowledge of the relative prices of inputs and outputs is not necessary when different measurement units of these inputs and outputs are used (Callens \& Tyteca, 1999). Major disadvantage of DEA is that the separation of inefficiency term from the stochastic noise is not possible (Wilson, 1995; Coelli et al., 2005). This problem arises because DEA does not contain an error term and therefore attributes all measurement error to inefficiency. The solution is by using 
bootstrapping techniques to establish a confidence interval of efficiency (Simar \& Wilson, 2007). DEA is a technique for measuring efficiency of a set of similar units, usually referred to as decision-making units or DMUs (Banker, 1984).

Scale efficiency measures the optimality of the firm's size. It is a measure related to the returns to scale in the production process (Forsund \& Hjalmarsson, 1979). It measures for a mix of inputs how a maximum output attained or how the firm is close to the optimal scale (Fried et al., 2008). Using DEA technique, scale efficiency could be calculated by dividing the technical efficiency estimated under constant return to scale (CRS) by technical efficiency estimated imposing variable return to scale (VRS). As noted by Fare et al. (1994), the nature of returns to scale can be measured using scale efficiency measure for any decision-making units or DMU.

The present study aimed at using the input orientated DEA model under the assumptions of CRS and VRS to measure the scale efficiency of dairy farms in Jordan. Scale efficiency of the sample dairy farms was investigated to allow estimation of an optimal size for a dairy farm in Jordan. DEA Frontier Software (DEA Frontier) was used to achieve the goals of the study in estimating the efficiency scores. This software uses Excel Solver as the engine for solving the DEA models (Zhu, 2009).

The present study covered the period from April 2011 to January 2012. Department of Statistics (DOS), Ministry of Agriculture (MOA), and the Agricultural Directorates (AD) in each governorate and other related sources were the secondary data sources for this study.

\section{Materials and Methods}

\subsection{Sample and Data}

The sample size was determined as a percentage of the total number of dairy farms in the country. Because the population of dairy farms is small, it is appropriate to consider a sample size of $20 \%$ of this population as a representative sample. Total number of 126 dairy farms was chosen to be surveyed. The sample was distributed among the whole country according to the total number of dairy farms in the three areas of the country (North, Middle, and South). Table 1 shows the number of dairy farms and percentages in country areas. The sample individual farms were randomly selected. Table 2 shows the distribution of the sample according to country areas. The surveyed farms were categorized to groups according to size based on number of dairy cows. Table 3 shows the sample according to size criterion.

The data was collected through personal interviews with farmers included in the sample. A structured questionnaire was designed to obtain information from interviewed farmers about capital, cow number, energy, labor, fodder, and veterinary services and drugs, and total amount of milk produced. Only 120 questionnaires out of 126 were considered. Six questionnaires were cancelled due to precession and lack of information reasons.

Table 1. Number of dairy farms and percentages in the country areas

\begin{tabular}{lcc}
\hline Area & Number of Dairy Farms & Percentage (of total) \\
\hline North & 289 & $46 \%$ \\
Middle & 320 & $51 \%$ \\
South & 019 & $03 \%$ \\
Total & 628 & $100 \%$ \\
\hline
\end{tabular}

Source: Alsharafat, 2013.

Table 2. Distribution of the sample according to country areas

\begin{tabular}{lcc}
\hline Area & Number of Surveyed Farms & Percentage (of sample) \\
\hline North & 55 & $46 \%$ \\
Middle & 61 & $51 \%$ \\
South & 04 & $03 \%$ \\
Total & 120 & $100 \%$ \\
\hline
\end{tabular}

Source: Calculated by the researcher based on source in Table 1. 
Table 3. Sample according to group size

\begin{tabular}{cccc}
\hline Group & No. of dairy cows & No. of Surveyed Farms & Percentage from Total Farms \\
\hline 1 & $1-25$ & 68 & $57 \%$ \\
2 & $26-50$ & 39 & $33 \%$ \\
3 & $51-75$ & 8 & $6 \%$ \\
4 & $>75$ & 5 & $4 \%$ \\
Total & & 120 & $100 \%$ \\
\hline
\end{tabular}

Source: Survey results.

\subsection{Analytical Framework}

Data Envelopment Analysis (DEA) technique was used for estimation of scale efficiency scores. The performance with regard of size of a set of peer entities called Decision Making Units or DMUs (the dairy farms in the present study) was evaluated by DEA. All efficiency scores in DEA range between 0 and 1 and lower scores indicate lower efficiency. The main aim is to measure the optimality of the farm's size. In DEA, the estimated frontier envelopes the input/output data of the most efficient decision making units (DMU), each farm in the analysis, consequently those DMU lying on the frontier are referred to as technically efficient with a score of 1 , while those below the frontier are regarded as inefficient, with a score of less than 1. According to the orientation chosen, two types of DEA models can be distinguished; the input-oriented and the output-oriented models. The input-oriented model indicates the potential proportional reduction in input usage, with output levels held constant, and the output-oriented models indicates the potential proportional increase in output production, with input levels held fixed, (Coelli et al., 2005). Charnes et al. (1978) model was an input orientated model in which inputs minimized and inefficiencies calculated in terms of the inputs. This procedure was followed in this study. This procedure is usually followed to achieve maximum feasible reductions in input quantities given input prices and output (Narges et al., 2011). Also, this procedure is followed because farmers typically have more short-term control over their input than output decisions (Battese and Coelli, 1992). The use of input oriented DEA models are more appropriate to reduce inputs consumed in the production process (Malana \& Malano, 2006; Chauhan et al., 2006). Calculation of scale efficiency (SE) assumes the calculation of technical efficiency (TE) measures. Technical efficiency scores can be obtained by running constant returns to scale (CRS) DEA model to achieve total or overall technical efficiency ( $\mathrm{TE}_{\mathrm{CRS}}$ ) and variable returns to scale (VRS) DEA model to achieve pure technical efficiency ( $\mathrm{TE}_{\mathrm{VRS}}$ ). If there is a difference between the scores of technical efficiency under CRS and VRS for a certain farm, the difference indicates that a farm is scale-inefficient. Scale efficiency measure can be calculated by dividing the total technical efficiency by pure technical efficiency:

$$
\mathrm{SE}=\mathrm{TE}_{\mathrm{CRS}} / \mathrm{TE} \mathrm{VRS}
$$

If $\mathrm{SE}=1$, then a farm is scale-efficient, its combination of inputs and outputs is efficient both under CRS and VRS and the farm is operating under increasing returns to scale. If $\mathrm{SE}<1$, then the combination of inputs and outputs is not scale-efficient and the farm is operating under decreasing returns to scale.

Used for comparative efficiency analysis, DEA method involves enveloped surfaces (efficient frontier) and efficient observations of decision-making units (DMUs). Figure 1 shows the overall technical efficiency (OTE), pure technical efficiency (PTE) and scale efficiency (SE). Total or overall technical efficiency (OTE) or (TE CRS $_{\text {), }}$ pure technical efficieny (PTE) or (TE $\mathrm{VRS}_{\text {) }}$, and scale (SE) can be calculated as follows:

$$
\begin{aligned}
\mathrm{TE}_{\mathrm{CRS}} & =\mathrm{PM} / \mathrm{PD} \\
\mathrm{TE}_{\mathrm{CRS}} & =\mathrm{PR} / \mathrm{PD} \\
\mathrm{TE}_{\mathrm{CRS}} & =\mathrm{PM} / \mathrm{PR}
\end{aligned}
$$




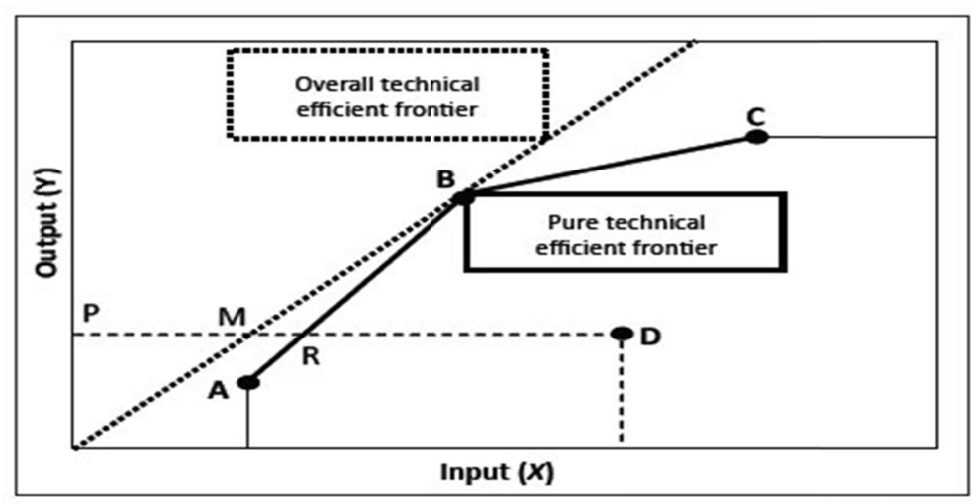

Figure 1. Components of the data envelopment analysis used

Source: Munize, 2002.

Technical efficiency scores for each group of dairy farms were obtained by solving both input-oriented DEA models under constant returns to scale (CRS) and under variable returns to scale (VRS). The input-oriented DEA model under constant returns to scale (CRS) is;

$$
\begin{array}{r}
\min \theta, \lambda \theta, \\
\text { subject to } \\
-\mathrm{yi}+\mathrm{Y} \lambda \geq 0 \\
\mathrm{xi}-\mathrm{X} \lambda \geq 0 \\
\lambda \geq 0
\end{array}
$$

where;

$\theta$ is the total technical efficiency score of $i_{\text {th }}$ farm and $\lambda$ is a $N x 1$ constants. The value of $\theta$ must satisfy the restriction: $\theta \leq 1$. If $\theta$ is equal to 1 , it indicates that the farm is on the production frontier and is a technically efficient firm.

The input-oriented DEA model under variable returns to scale (VRS) is;

$$
\begin{array}{r}
\min \theta, \lambda \theta, \\
\text { subject to } \\
-\mathrm{yi}+\mathrm{Y} \lambda \geq 0 \\
\mathrm{xi}-\mathrm{X} \lambda \geq 0 \\
\mathrm{~N} 1 / \lambda=1 \\
\lambda \geq 0
\end{array}
$$

where;

$\mathrm{N} 1 / \lambda=1$ is a convexity constraint which ensures that an inefficient farm is only benchmarked against farms of a similar size. $\theta$ is the technical efficiency or the pure technical efficiency score of the $\mathrm{i}_{\text {th }}$ firm.

The variables defined for efficiency calculation include input variables and output variable. Inputs are those to be purchased: capital (fixed equipments and buildings), average dairy cow number, energy (oil and electricity), labor (family and hired labor), fodder (concentrates and minerals), and veterinary services and drugs. Output consisted mainly of total amount of milk produced. The number of dairy cows at the farm considered as a measure of size (scale). Data related to inputs and output for the sampled farms is summarized in Table 4. 
Table 4. Descriptive statistics for the sample during study reference period

\begin{tabular}{lcc}
\hline Inputs & Mean & Standard Deviation \\
\hline Capital (JDs) & 68579.5 & 31205.8 \\
Cow number & 27 & 13.1 \\
Energy Cost (JDs) & 1800 & 857.3 \\
Labor Cost; family \& hired (JDs) & 3225 & 1489.8 \\
Fodder Cost (JDs) & 39877 & 17850.6 \\
Veterinary Services Cost (JDs) & 1250 & 587.7 \\
Output & & \\
Milk (kg) & 4867.3 & 1987.8 \\
\hline
\end{tabular}

Source: Survey results.

\section{Results and Discussion}

The main objective of this study was to determine the levels of scale efficiency on a sample of Jordanian dairy farms using DEA technique. Farm level technical and scale input oriented efficiencies were calculated according to the DEA methodology mentioned above. A summary of the results on the overall technical efficiency ( $\mathrm{TE}_{\mathrm{CRS}}$ ), pure technical efficiency $\left(\mathrm{TE}_{\mathrm{VRS}}\right)$, and scale efficiency (SE) are presented in Table 5.

Table 5. Technical and scale input oriented efficiencies of the investigated farms

\begin{tabular}{rllll} 
& Group & $\mathrm{TE}_{\mathrm{CRS}}{ }^{1}$ & $\mathrm{TE}_{\mathrm{VRS}}{ }^{2}$ & $\mathrm{SE}^{3}$ \\
\hline 1 & 0.287 & 0.394 & 0.728 \\
2 & 0.207 & 0.315 & 0.657 \\
3 & 0.196 & 0.304 & 0.644 \\
4 & 0.181 & 0.298 & 0.607 \\
${ }^{1}$ Overall technical efficiency, ${ }^{2}$ Pure technical efficiency, ${ }^{3}$ Scale efficiency.
\end{tabular}

The results shown in Table 5 indicates that on average the investigated farms were technically inefficient either under constant returns to scale or under variable returns to scale highlighting a potential for them to improve their level of technical efficiency. This inefficiency indicates that dairy producers were overusing inputs to produce their level of output. The results also reveal that the investigated farms are scale-inefficient since SE $<1$ for all farms; this indicates that the combination of inputs is not efficient and the farms are operating under decreasing returns to scale. The results in Table 5 shows that farms in group 1 are the most efficient farms with respect to farm size in spite of the fact that all the farms were scale inefficient. Group 1 (1-25 cows) is the smallest. Most of the dairy farms in Jordan are family operated production units with a small scale (Alsharafat, 2013). This is the reason that more than half of the surveyed farms (57\%) in this study were small with less than 25 heads. In this group, inputs are better allocated due to fewer operations and less costs needed to accomplish these operations. Under constant returns to scale (CRS) the mean technical efficiency score across the 120 farms was 0.217 ranging from a minimum of 0.181 for group 4 to a maximum of 0.287 for group 1 . Under variable scale to returns (VRS), the mean technical efficiency score was 0.328 ranging from a minimum of 0.298 for group 4 to a maximum of 0.394 for group 1. Hence, the technical efficiency scores under VRS were on average higher than those under CRS. The differences in mean efficiency scores under the two different returns to scale assumptions highlight that scale inefficiency was present. All the sampled farms were scale-inefficient under both CRS and VRS. Technical inefficiency under both CRS and VRS is partly because these farms operate at an inefficient scale. As shown in Table 5, the technical efficiency is higher with decrease in farm size indicating scale efficiency. An increase in farm size is a principal mean of action the farm manager has at his disposal for enhancing the technical efficiency of his farm. The positive effect of farm size on technical efficiency highlights the existing resource-saving 
potential that results from scale effects. Many authors found at least a slightly positive relationship between efficiency and farm size (Heshmati \& Kumbhakar, 1997; Wilson et al., 1998; Helfand \& Levine, 2004).

\section{Conclusions}

The study aimed at calculating farm level technical and scale input oriented efficiencies according to the DEA methodology. The results showed that all the sampled farms were scale-inefficient under both constant returns to scale and variable returns to scale. Data Envelopment Analysis (DEA) technique estimation of scale efficiency scores showed that on average the majority of Jordanian dairy farmers during the study reference period were not operating at maximum scale efficiency and have a marked potential to improve. In other words, they were inefficient producers with the size of their farms. Scale inefficiency was a significant contributor to the technical inefficiency experienced by farms. If dairy farms in Jordan were to increase their scale of operation, the overall degree of technical efficiency should increase. Farm extension services providers can assist in identifying the best management practices and give advice to farmers on how to improve their technical efficiency.

\section{Acknowledgment}

The author wish to express his deep sense of gratitude to the farmers who participated in the survey, Agricultural Directorates across the entire country, Department of Statistics staff, and the Ministry of Agriculture staff. He would also like to convey thanks to the Faculty of Agriculture members at Jerash University for their help.

\section{References}

Aigner, D., Lovell, C. A. K., \& Schmidt, P. (1977). Formulation and estimation of stochastic frontier production function models. Journal of Econometrics, 6, 21-37. http://dx.doi.org/10.1016/0304-4076(77)90052-5

Ali, Al-Sharafat. (2013). Technical Efficiency of Dairy Farms: A Stochastic Frontier Application on Dairy Farms in Jordan. Journal of Agricultural Science, 5(3), 45-53. http://dx.doi.org/10.5539/jas.v5n3p45

Banker, R. D. (1984). Estimating Most Productive Scale Size using Data Envelopment Analysis. European Journal of Operational Research, 17(1), 35-44. http://dx.doi.org/10.1016/0377-2217(84)90006-7

Barnes, A. P. (2006). Does multi-functionality affect technical efficiency? A non-parametric analysis of the Scottish dairy industry. Journal of Environmental Management, 80, 287-294. http://dx.doi.org/10.1016/j.jenvman.2005.09.020

Battese, G. E., \& Coelli, T. J. (1992). Frontier Production Functions, Technical Efficiency and Panel Data: With Application to Paddy Farmers in India. Journal of Productivity Analysis, 3, 153-169. http://dx.doi.org/10.1007/BF00158774

Callens, I., \& Tyteca, D. (1999). Towards indicators of sustainable de-velopment for firms: a productive efficiency perspective. Ecological Eco-nomics, 28(1), 41-53. http://dx.doi.org/10.1016/S0921-8009(98)00035-4

Charnes, A., Cooper, W. W., \& Rhodes, E. (1978). Measuring efficiency of decision making units. European Journal of Operational Research, 2, 429-444. http://dx.doi.org/10.1016/0377-2217(78)90138-8

Coelli, T. J., Prasada Rao, D. S., O'Donnell, C. J., \& Battese, G. E. (2005). An introduction to efficiency and productivity analysis (2nd Edn). New York, USA: Springer.

Dalton, T. J. (2004). Indivisibility and spatial components of dairy firm inefficiency. American Agricultural Economics Associations Annual Meeting, August 1-4, Denver, Colorado. USA.

D'Haese, M., Speelman, S., Alary, V., Tillard, E., \& D'Haese, L. (2009). Efficiency in milk production on Reunion Island: Dealing with land scarcity. Journal of Dairy Science, 92, 3676-3683. http://dx.doi.org/10.3168/jds.2008-1874

Fare, R., Grosskopf, S., \& Lovell, C. A. K. (1994). Production frontiers. Cambridge: Cambridge University Press.

Farrell, M. J. (1957). The measurement of productive efficiency. Journal of Royal Statistics of Society, 120, 253-290. http://dx.doi.org/10.2307/2343100

Forsund, F. R., \& Hjalmarsson, L. (1979). Generalized Farrell Measures of Efficiency: An Application to Milk Processing in Swedish Dairy Plants. The Economic Journal, 89, 294-315. http://dx.doi.org/10.2307/2231603

Fraser, I., \& Coridna, D. (1999). An application of data envelopment analysis to irrigated dairy farms in Northern Victoria. Australia Agricultural Systems, 59, 267-282. http://dx.doi.org/10.1016/S0308-521X(99)00009-8

Fried, H. O., Knox-Lovell, C. A., \& Schmidt, S. S. (2008). The measure-ment of productive efficiency and productivity growth. New-York: Oxford University Press. 
Helfand, S. M., \& Leveine, E. S. (2004). Farm size and the determinants of productive efficiency in the Brazilian Center-West. Agricultural Economics, 31, 241-249.

Heshamati, A., \& Kumbhakar, S. C. (1997). Estimation of technical efficiency in Swedish crop farms: a pseudo panel data approach. Journal of Agricultural Economics, 48(1), 22-37. http://dx.doi.org/10.1111/j.1477-9552.1997.tb01128.x

Jaforullah, M., \& Whiteman, J. (1999). Scale efficiency in the New Zealand dairy industry: A non-parametric approach. The Australian Journal of Agricultural and Resource Economics, 43, 523-541. http://dx.doi.org/10.1111/1467-8489.00093

Latruffe, L., Balcombe, K., Davidova, S., \& Zawalinska, K. (2005). Technical and scale efficiency of crop and livestock farms in Poland: Does specialization matter? Agricultural Economics, 32, 281-296. http://dx.doi.org/10.1111/j.1574-0862.2005.00322.x

Malana, N. M., \& Malano, H. M. (2006). Benchmarking productive efficiency of selected wheat areas in Pakistan and India - data envelopment analysis. Irrig. Drain, 55, 383-394. http://dx.doi.org/10.1002/ird.264

Mbaga, D. M., Romain, R., Larue, B., \& Lebel, L. (2003). Assessing technical efficiency of Quebec dairy farms. Canadian Journal of Agricultural Economics, 51, 121-137. http:dx.doi.org/10.1111/j.1744-7976.2003.tb00169.x

Ministry of Agriculture, Jordan, MoA. (2011). Annual Report.

Minh, N. K., \& Long, G. T. (2009). Efficiency Estimates for Agricultural Production in Vietnam: A Comparison of Parametric and Non parametric Approaches. Agricultural Economics Review, 10, $62-78$.

Muniz, M. A., (2002). Separating managerial inefficiency and external conditions in data envelopment analysis. European Journal of Operation Research, 143, 625-643. http://dx.doi.org/10.1016/S0377-2217(01)00344-7

Narges, B., Mahmoud, O., \& Hojat, A. (2011). Application of Data Envelopment Analysis to Evaluate Efficiency of Commercial Greenhouse Strawberry. Research Journal of Applied Sciences, Engineering and Technology, 3(3), 185-193.

Russell, N. P., \& Young, T. (1983). Frontier production functions and the Measurement of technical efficiency. Journal of Agricultural Ecoomics, 34, 139-50. http://dx.doi.org/10.1111/j.1477-9552.1983.tb00984.x

Seiford, L. M., \& Thrall, R. M. (1990). Recent developments in DEA: the mathematical programming approach to frontier analysis. Journal of Econometrics, 46, 7-38. http://dx.doi.org/10.1016/0304-4076(90)90045-U

Simar, L., \& Wilson, P. W. (2007). Estimation and inference in two-stage, semi-parametric models of production processes. Journal of Econometrics, 136, 31-64. http://dx.doi.org/10.1016/j.jeconom.2005.07.009

Wilson, P. W. (1995). Detecting influential observations in data envelop-ment analysis. Journal of Productivity Analysis, 6, 27-45. http://dx.doi.org/10.1007/BF01073493

Wilson, P., Hadly, D., Ramsden, S., \& Kaltsas, I. (1998). Measuring and explaining technical efficiency in UK potato production. Journal of Agricultural Economics, 49(3), 294-305. http://dx.doi.org/10.1111/j.1477-9552.1998.tb01273.x

Zhu, J. (2009). Quantitative models for performance evaluation and benchmarking; data envelopment analysis with spreadsheets (1st ed.). USA: Springer. http://dx.doi.org/10.1007/978-0-387-85982-8

\section{Copyrights}

Copyright for this article is retained by the author(s), with first publication rights granted to the journal.

This is an open-access article distributed under the terms and conditions of the Creative Commons Attribution license (http://creativecommons.org/licenses/by/3.0/). 